\title{
Ion Exchange of Layer-Structured Titanate $\mathrm{Cs}_{\mathrm{x}} \mathrm{Ti}_{2-x / 2} \mathrm{Mg}_{x / 2} \mathrm{O}_{4}(x=0.70)$ and Applications as Cathode Materials for Both Lithium- and Sodium-Ion Batteries
}

\author{
Masao Ohashi \\ Tokuyama College of Technology, Shunan City, Japan \\ Email: oohasi@tokuyama.ac.jp
}

How to cite this paper: Ohashi, M. (2019) Ion Exchange of Layer-Structured Titanate $\mathrm{Cs}_{x} \mathrm{Ti}_{2-x / 2} \mathrm{Mg}_{x / 2} \mathrm{O}_{4}(x=0.70)$ and Applications as Cathode Materials for Both Lithium- and Sodium-Ion Batteries. Materials Sciences and Applications, 10, 150-157. https://doi.org/10.4236/msa.2019.102012

Received: February 13, 2019

Accepted: February 24, 2019

Published: February 27, 2019

Copyright $\odot 2019$ by author(s) and Scientific Research Publishing Inc. This work is licensed under the Creative Commons Attribution International License (CC BY 4.0).

http://creativecommons.org/licenses/by/4.0/ (c) (i) Open Access

\begin{abstract}
Cathode materials for rechargeable batteries have been extensively investigated. Sodium-ion batteries are emerging as alternatives to lithium-ion batteries. In this study, a novel cathode material for both lithium- and sodium-ion batteries has been derived from a layered crystal. Layer-structured titanate $\mathrm{Cs}_{x} \mathrm{Ti}_{2-x / 2} \mathrm{Mg}_{x / 2} \mathrm{O}_{4}(x=0.70)$ with lepidocrocite $(\gamma-\mathrm{FeOOH})$-type structure has been prepared in a solid-state reaction from $\mathrm{Cs}_{2} \mathrm{CO}_{3}$, anatase-type $\mathrm{TiO}_{2}$, and $\mathrm{MgO}$ at $800^{\circ} \mathrm{C}$. Ion-exchange reactions of $\mathrm{Cs}^{+}$in the interlayer space were studied in aqueous solutions. The single phases of $\mathrm{Li}^{+}, \mathrm{Na}^{+}$, and $\mathrm{H}^{+}$exchange products were obtained, and these were found to contain interlayer water. The interlayer water in the lithium ion-exchange product was removed by heating at $180^{\circ} \mathrm{C}$ in vacuum. The resulting titanate $\mathrm{Li}_{0.53} \mathrm{H}_{0.13} \mathrm{Cs}_{0.14} \mathrm{Ti}_{1.65} \mathrm{Mg}_{0.30} \mathrm{O}_{4}$ was evaluated for use as cathodes in both rechargeable lithium and sodium batteries. The $\mathrm{Li}^{+}$intercalation-deintercalation capacities were found to be $151 \mathrm{mAh} / \mathrm{g}$ and $114 \mathrm{mAh} / \mathrm{g}$, respectively, for the first cycle in the voltage range $1.0-3.5 \mathrm{~V}$. The amounts of $\mathrm{Li}^{+}$corresponded to 0.98 and 0.74 of the formula unit, respectively. The $\mathrm{Na}^{+}$intercalation-deintercalation capacities were $91 \mathrm{mAh} / \mathrm{g}$ and $77 \mathrm{mAh} / \mathrm{g}$, respectively, for the first cycle in the voltage range $0.70-3.5 \mathrm{~V}$. The amounts of $\mathrm{Na}^{+}$corresponded to 0.59 and 0.50 of the formula unit, respectively. The new cathode material derived from the layer-structured titanate is non-toxic, inexpensive, and environmentally benign.
\end{abstract}

\section{Keywords}

Cathode Material, Layer-Structured Titanate, Lithium Battery, Sodium Battery, Environmentally Benign 


\section{Introduction}

We have studied the characterizations of layer-structured titanates with lepidocrocite $(\gamma-\mathrm{FeOOH})$-type structure [1]-[7]. In a previous study [6], we showed that the $\mathrm{Li}^{+}$exchange product of $\mathrm{Li}_{0.60} \mathrm{H}_{0.04} \mathrm{Cs}_{0.06} \mathrm{Ti}_{1.30} \mathrm{Fe}_{0.70} \mathrm{O}_{4}$, derived by the ion-exchange reaction from $\mathrm{Cs}_{x} \mathrm{Ti}_{2-x} \mathrm{Fe}_{x} \mathrm{O}_{4}(x=0.70)$ with lepidocrocite-type structure, exhibited discharge and charge capacities of 110 and $92 \mathrm{mAh} / \mathrm{g}$, respectively, for the first cycle in a rechargeable lithium battery in the voltage range $1.5-4.2 \mathrm{~V}$. The discharge-charge capacity almost corresponds to a redox reaction of $\mathrm{Fe}^{3+} / \mathrm{Fe}^{2+}$ in the titanate. However, the discharge-charge curves showed that there is a small amount of rechargeable capacity corresponding to a $\mathrm{Ti}^{4+} / \mathrm{Ti}^{3+}$ redox couple. Recently, we reported that the $\mathrm{Li}^{+}$exchange product of $\mathrm{Li}_{2} \mathrm{Ti}_{5} \mathrm{O}_{11}$, derived by the ion-exchange reaction from layer-structured titanate $\mathrm{Cs}_{2} \mathrm{Ti}_{5} \mathrm{O}_{11}$, exhibited discharge-charge capacities of 120 and $100 \mathrm{mAh}$, respectively, for the first cycle in a rechargeable sodium battery in the voltage range $0.70-4.0 \mathrm{~V}$ [8]. These discharge-charge capacities obviously correspond to a $\mathrm{Ti}^{4+} / \mathrm{Ti}^{3+}$ redox couple in the layer-structured titanate. In the present study, we showed that the $\mathrm{Ti}^{4+} / \mathrm{Ti}^{3+}$ redox couple in the lepidocrocite-type layer structure exhibits considerable discharge-charge capacities by the electrochemical intercalation-deintercalation of both $\mathrm{Li}^{+}$and $\mathrm{Na}^{+}$.

The crystal structure of $\mathrm{Cs}_{x} \mathrm{Ti}_{2-x / 2} \mathrm{Mg}_{x / 2} \mathrm{O}_{4}(x=0.70)$ is drawn in Figure 1 using the atomic parameters reported by Reid et al. [9]. Each stacking layer consists of a corrugated layer of titanium-oxygen. A portion of the $\mathrm{Ti}^{4+}$ ions $(x / 2=0.35$ for formula unit) in the octahedral position ( 2 for formula unit) is substituted with lower-valent $\mathrm{Mg}^{2+}$ ions. The charge balance is maintained by eight-coordinated interlayer $\mathrm{Cs}^{+}$ions from oxygen atoms in the layers. The partial occupancy of $\mathrm{x}=$ 0.70 by $\mathrm{Cs}^{+}$in the interlayer positions is attributed to the overcrowding of $\mathrm{Cs}^{+}$ with the large ionic radius [9].

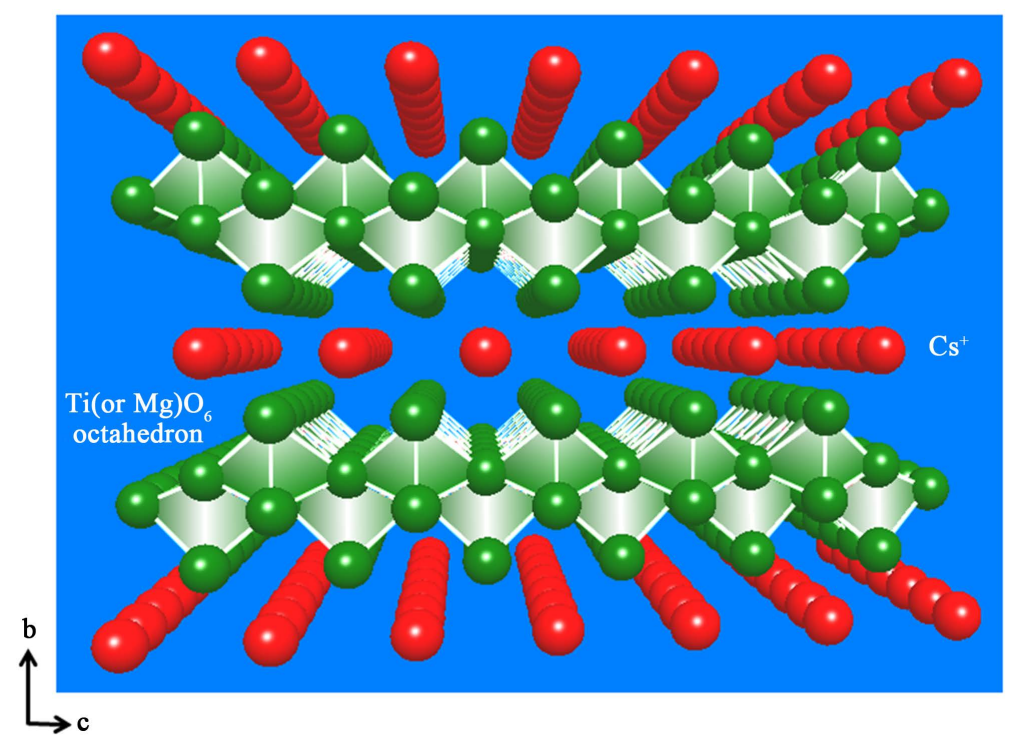

Figure 1. Structure of $\mathrm{Cs}_{x} \mathrm{Ti}_{2-x} \mathrm{Mg}_{x} \mathrm{O}_{4}(x=0.70)$ as seen from the direction of the a-axis. 


\section{Experimental}

All chemicals used were High Special Grade (Wako Chemical Industries, Ltd., Japan) and were used without further purification. The layer-structured titanate $\mathrm{Cs}_{x} \mathrm{Ti}_{2-x / 2} \mathrm{Mg}_{x / 2} \mathrm{O}_{4}(x=0.70)$ with lepidocrocite-type structure has been prepared in a solid-state reaction using $\mathrm{Cs}_{2} \mathrm{CO}_{3}$, anatase-type $\mathrm{TiO}_{2}$, and $\mathrm{MgO}$ at $800^{\circ} \mathrm{C}$, according to a similar method reported by Reid et al. [9]. The mixture with the desired ratio was heated at $800^{\circ} \mathrm{C}$ for $20 \mathrm{~h}$, and the resulting powder was ground and heated again at $800^{\circ} \mathrm{C}$ for $20 \mathrm{~h} . \mathrm{Li}^{+}$and $\mathrm{Na}^{+}$exchange were performed using 1.0- $\mathrm{mol} / \mathrm{L}_{\mathrm{LiNO}_{3}}$ and $\mathrm{NaNO}_{3}$ solutions for $9 \mathrm{~d}$ at $60^{\circ} \mathrm{C}$. The solutions were changed every $3 \mathrm{~d}$. The $\mathrm{H}^{+}$exchange was carried out using 0.05-mol/ $\mathrm{L} \mathrm{H}_{2} \mathrm{SO}_{4}$ solution for $3 \mathrm{~d}$ at room temperature between $15^{\circ} \mathrm{C}-25^{\circ} \mathrm{C}$, changing the solution every day.

Powder X-ray diffraction (XRD) patterns were collected on a Rigaku Ultima IV diffractometer over a $2 \theta$ range $10^{\circ}-60^{\circ}$ using graphite-monochromatized $\mathrm{Cu}-\mathrm{K} \alpha$ radiation $(\lambda=0.15405 \mathrm{~nm})$. The contents of $\mathrm{Cs}, \mathrm{Li}$ and $\mathrm{Na}$ in the samples were determined by the atomic absorption method after dissolving the samples in a mixed-acid solution with $\mathrm{H}_{2} \mathrm{SO}_{4}$ and $\mathrm{HF}$. The $\mathrm{Mg}$ content was determined by gravimetric technique using cupferron $\left(\mathrm{C}_{6} \mathrm{H}_{9} \mathrm{~N}_{3} \mathrm{O}_{2}\right)$ for the chelating agent. Dehydration processes were studied by TG-DTA at a heating rate of $10^{\circ} \mathrm{C} / \mathrm{min}$. A cathode was formed of a mixture of the titanate powder ( $80 \mathrm{wt} \%$ ), acetylene black (10 wt\%), and PTFE binder (10 wt\%), pressed into a stainless-steel grid under a pressure of $100 \mathrm{MPa}$. The electrolyte of the lithium battery was a 1.0-mol/L $\mathrm{LiPF}_{6}$ solution of 1:1 mixture of ethylene carbonate (EC) and dimethyl carbonate (DME). The electrolyte of the sodium battery was a $1.0-\mathrm{mol} / \mathrm{L} \mathrm{NaClO}_{4}$ solution of propylene carbonate (PC). The lithium battery was first discharge and cycled between $1.0 \mathrm{~V}$ and $3.5 \mathrm{~V}$ at $0.10 \mathrm{~mA} / \mathrm{cm}^{2}$ in an Ar-filled glove box at room temperature between $15^{\circ} \mathrm{C}-25^{\circ} \mathrm{C}$. The sodium cell was also first discharge and cycled between $0.70 \mathrm{~V}$ and $3.5 \mathrm{~V}$ at $0.10 \mathrm{~mA} / \mathrm{cm}^{2}$.

\section{Results and Discussion}

\subsection{Crystal Structure}

The XRD pattern of $\mathrm{Cs}_{x} \mathrm{Ti}_{2-x / 2} \mathrm{Mg}_{x / 2} \mathrm{O}_{4}(x=0.70)$ (Figure 2(a)) was indexed on the basis of an orthorhombic cell of $\mathrm{a}=0.3824$ (2) $\mathrm{nm}, \mathrm{b}=1.704$ (3) $\mathrm{nm}$, and $\mathrm{c}=$ 0.2929 (1) $\mathrm{nm}$ (Table 1). The lattice constants of the sample are in good agreement with those prepared by Reid et al. $(\mathrm{a}=0.3821 \mathrm{~nm}, \mathrm{~b}=1.7040 \mathrm{~nm}$ and $\mathrm{c}=$ $0.2981 \mathrm{~nm})$ [9].

\subsection{Ion Exchange}

The XRD pattern of the $\mathrm{Li}^{+}$exchange product is shown in Figure 2(b). The pattern was indexed as a single phase with orthorhombic lattice constants of $\mathrm{a}=$ $0.378 \mathrm{~nm}, \mathrm{~b}=1.72 \mathrm{~nm}$, and $\mathrm{c}=0.292 \mathrm{~nm}$ (Table 1). The lattice constants of a and $\mathrm{c}$ were almost unchanged. This shows that the host layer of $\mathrm{Cs}_{x} \mathrm{Ti}_{2-x / 2} \mathrm{Mg}_{x / 2} \mathrm{O}_{4}$ $(x=0.70)$ is maintained through the $\mathrm{Li}^{+}$exchange. The interlayer spacing which 


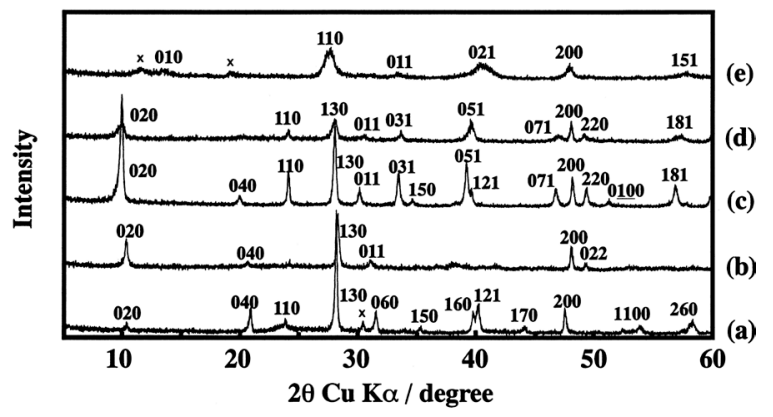

Figure 2. XRD patterns of (a) $\mathrm{Cs}_{0.70} \mathrm{Ti}_{1.65} \mathrm{Mg}_{0.35} \mathrm{O}_{4}$; (b) $\mathrm{Li}_{0.53} \mathrm{H}_{0.13} \mathrm{Cs}_{0.14} \mathrm{Ti}_{1.65} \mathrm{Mg}_{0.30} \mathrm{O}_{4} \cdot 0.92 \mathrm{H}_{2} \mathrm{O}$; (c) $\mathrm{Na}_{0.56} \mathrm{H}_{0.14} \mathrm{Ti}_{1.65} \mathrm{Mg}_{0.35} \mathrm{O}_{4} \cdot 1.1 \mathrm{H}_{2} \mathrm{O}$; (d) $\mathrm{H}_{0.99} \mathrm{Cs}_{0.07} \mathrm{Ti}_{1.65} \mathrm{Mg}_{0.17} \mathrm{O}_{4} \cdot 1.2 \mathrm{H}_{2} \mathrm{O}$; (e) $\mathrm{Li}_{0.53} \mathrm{H}_{0.13} \mathrm{Cs}_{0.14} \mathrm{Ti}_{1.65} \mathrm{Mg}_{0.30} \mathrm{O}_{4}$ (x: unknown peaks).

Table 1. Compositions and orthorhombic lattice constants of the products.

\begin{tabular}{cccc}
\hline Compositions & $\mathrm{a} / \mathrm{nm}$ & $\mathrm{b} / \mathrm{nm}$ & $\mathrm{c} / \mathrm{nm}$ \\
\hline $\mathrm{Cs}_{0.70} \mathrm{Ti}_{1.65} \mathrm{Mg}_{0.35} \mathrm{O}_{4}$ & $0.3824(2)$ & $1.704(3)$ & $0.2929(1)$ \\
$\mathrm{Li}_{0.53} \mathrm{H}_{0.13} \mathrm{Cs}_{0.14} \mathrm{Ti}_{1.65} \mathrm{Mg}_{0.30} \mathrm{O}_{4} \cdot 0.92 \mathrm{H}_{2} \mathrm{O}$ & 0.378 & 1.72 & 0.292 \\
$\mathrm{Na}_{0.56} \mathrm{H}_{0.14} \mathrm{Ti}_{1.65} \mathrm{Mg}_{0.35} \mathrm{O}_{4} \cdot 1.1 \mathrm{H}_{2} \mathrm{O}$ & 0.378 & 1.78 & 0.301 \\
$\mathrm{H}_{0.99} \mathrm{Cs}_{0.07} \mathrm{Ti}_{1.65} \mathrm{Mg}_{0.17} \mathrm{O}_{4} \cdot 1.2 \mathrm{H}_{2} \mathrm{O}$ & 0.379 & 1.77 & 0.298 \\
$\mathrm{Li}_{0.53} \mathrm{H}_{0.13} \mathrm{Cs}_{0.14} \mathrm{Ti}_{1.65} \mathrm{Mg}_{0.30} \mathrm{O}_{4}$ & 0.371 & 0.662 & 0.300
\end{tabular}

corresponds to $\mathrm{b} / 2$, increased from $0.852 \mathrm{~nm}$ to $0.860 \mathrm{~nm}$. The TGA curve of the product (Figure $3(\mathrm{a})$ ) shows a weight loss from $20^{\circ} \mathrm{C}$ to $200^{\circ} \mathrm{C}$ corresponding to the dehydration of interlayer water. The composition was estimated to be $\mathrm{Li}_{0.53} \mathrm{H}_{0.13} \mathrm{Cs}_{0.14} \mathrm{Ti}_{1.65} \mathrm{Mg}_{0.30} \mathrm{O}_{4} \cdot 0.92 \mathrm{H}_{2} \mathrm{O}$ by chemical analysis and weight loss. It was found that $14 \%$ of the $\mathrm{Mg}$ in the titanate was leached out in solution during the ion exchange. England et al. [10] also studied the $\mathrm{Li}^{+}$exchange product and estimated the composition to be $\mathrm{Li}_{0.33} \mathrm{Cs}_{0.37} \mathrm{Ti}_{1.65} \mathrm{Mg}_{0.35} \mathrm{O}_{4} \cdot 0.72 \mathrm{H}_{2} \mathrm{O}$ by the amount of $\mathrm{Cs}$ released into solution, determined by photometric analyses and weight loss from TG analysis. They did not analyze the content of $\mathrm{Mg}$ in their $\mathrm{Li}^{+}$-exchanged product.

The $\mathrm{Li}^{+}$-exchange product was heated at $180^{\circ} \mathrm{C}$ for $1 \mathrm{~h}$ in a vacuum (Figure $2(\mathrm{e})$ ). The XRD pattern was indexed as a single phase with orthorhombic lattice constants of $\mathrm{a}=0.371 \mathrm{~nm}, \mathrm{~b}=0.662 \mathrm{~nm}$, and $\mathrm{c}=0.300 \mathrm{~nm}$ (Table 1). In this case, the lattice constant of $\mathrm{b}$ corresponds to the interlayer spacing. The interlayer spacing decreased from $0.860 \mathrm{~nm}$ to $0.662 \mathrm{~nm}$ because of dehydration of the interlayer water. The dehydrated product of $\mathrm{Li}_{0.53} \mathrm{H}_{0.13} \mathrm{Cs}_{0.14} \mathrm{Ti}_{1.65} \mathrm{Mg}_{0.30} \mathrm{O}_{4}$ was evaluated for its uses as cathodes in both lithium and sodium batteries.

The XRD pattern of the $\mathrm{Na}^{+}$exchange product showed that the product was a mixture of two phases with the interlayer spacing of $d=1.14 \mathrm{~nm}$ and $\mathrm{d}=0.89$ $\mathrm{nm}$. This product was heated at $40^{\circ} \mathrm{C}$ for $1 \mathrm{~h}$. Figure $2(\mathrm{c})$ shows the XRD pattern of the heated product. The pattern was indexed as a single phase with the orthorhombic lattice constants (Table 1) where the $0.110-\mathrm{nm}$ phase disappeared. These constants show that the host layer of $\mathrm{Cs}_{x} \mathrm{Ti}_{2-x / 2} \mathrm{Mg}_{x / 2} \mathrm{O}_{4}(x=0.70)$ is 


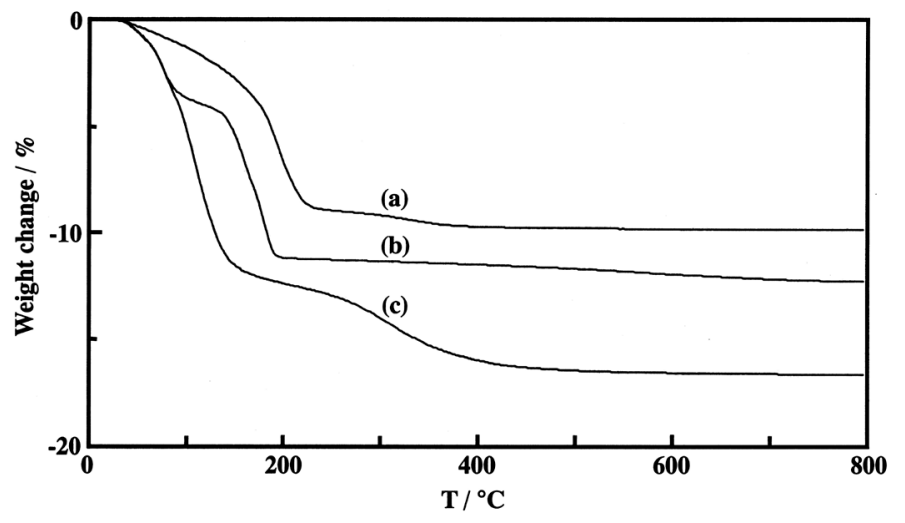

Figure 3. TGA curves of (a) $\mathrm{Li}_{0.53} \mathrm{H}_{0.13} \mathrm{Cs}_{0.14} \mathrm{Ti}_{1.65} \mathrm{Mg}_{0.30} \mathrm{O}_{4} \cdot 0.92 \mathrm{H}_{2} \mathrm{O}$; (b) $\mathrm{Na}_{0.56} \mathrm{H}_{0.14} \mathrm{Ti}_{1.65} \mathrm{Mg}_{0.35} \mathrm{O}_{4} \cdot 1.1 \mathrm{H}_{2} \mathrm{O}$; (c) $\mathrm{H}_{0.99} \mathrm{Cs}_{0.07} \mathrm{Ti}_{1.65} \mathrm{Mg}_{0.17} \mathrm{O}_{4} \cdot 1.2 \mathrm{H}_{2} \mathrm{O}$.

also maintained through the $\mathrm{Na}^{+}$exchange. The TGA curve (Figure 3(b)) shows two steps of weight loss: $20^{\circ} \mathrm{C}-100^{\circ} \mathrm{C}$ and $100^{\circ} \mathrm{C}-200^{\circ} \mathrm{C}$. Both steps correspond to the dehydration of the interlayer water. The composition was estimated to be $\mathrm{Na}_{0.56} \mathrm{H}_{0.14} \mathrm{Ti}_{1.65} \mathrm{Mg}_{0.35} \mathrm{O}_{4} \cdot 1.1 \mathrm{H}_{2} \mathrm{O}$ (Table 1). England et al. [10] also studied the $\mathrm{Na}^{+}$ exchange product and determined the composition to be $\mathrm{Na}_{0.70} \mathrm{Ti}_{1.65} \mathrm{Mg}_{0.35} \mathrm{O}_{4} \cdot 0.70 \mathrm{H}_{2} \mathrm{O}$.

The XRD pattern of the $\mathrm{H}^{+}$exchange product is shown in Figure 2(d). The pattern was indexed as a single phase with the orthorhombic lattice constants of $\mathrm{a}=0.378 \mathrm{~nm}, \mathrm{~b}=1.77 \mathrm{~nm}$, and $\mathrm{c}=0.298 \mathrm{~nm}$ (Table 1). This also shows that the host layer of $\mathrm{Cs}_{x} \mathrm{Ti}_{2-x / 2} \mathrm{Mg}_{x / 2} \mathrm{O}_{4}(x=0.70)$ is maintained through the $\mathrm{H}^{+}$exchange. The TGA curve (Figure $3(\mathrm{c})$ ) shows two steps of weight loss: $20^{\circ} \mathrm{C}-150^{\circ} \mathrm{C}$ and $150^{\circ} \mathrm{C}-450^{\circ} \mathrm{C}$. The former weight loss corresponds to the dehydration of the interlayer water, and the latter corresponds to dehydration of the decomposition due to the combination of the exchanged $\mathrm{H}^{+}$with the $\mathrm{O}^{2-}$ of the host layer. The composition was estimated to be $\mathrm{H}_{0.99} \mathrm{Cs}_{0.07} \mathrm{Ti}_{1.65} \mathrm{Mg}_{0.17} \mathrm{O}_{4} \cdot 1.2 \mathrm{H}_{2} \mathrm{O}$ (Table 1). It was found that $51 \%$ of $\mathrm{Mg}$ in the titanate was leached out in solution during the ion exchange. England et al. [10] studied the $\mathrm{H}^{+}$exchange product and estimated the composition to be $\mathrm{H}_{0.65} \mathrm{Cs}_{0.05} \mathrm{Ti}_{1.65} \mathrm{Mg}_{0.35} \mathrm{O}_{4} \cdot 0.7 \mathrm{H}_{2} \mathrm{O}$.

\subsection{Lithium Battery}

Figure 4 shows the discharge-charge curves of the $\mathrm{Li} / \mathrm{Li}_{0.53} \mathrm{H}_{0.13} \mathrm{Cs}_{0.14} \mathrm{Ti}_{1.65} \mathrm{Mg}_{0.30} \mathrm{O}_{4}$ cell. The cell voltage decreased rapidly from the rest potential of $3.1 \mathrm{~V}$ to $2.0 \mathrm{~V}$ and then decreased slowly to the cutoff voltage of $1.0 \mathrm{~V}$. The discharge capacity was $151 \mathrm{mAh} / \mathrm{g}$ for the first cycle. The amount of $\mathrm{Li}^{+}$intercalated in this process was 0.98 for the formula unit. The discharge potentials of $\mathrm{Ti}^{4+} / \mathrm{Ti}^{3+}$ in a $\mathrm{Li}_{4 / 3} \mathrm{Ti}_{5 / 3} \mathrm{O}_{4}$ spinel oxide is reported to be $1.55 \mathrm{~V}$, with the insertion of $\mathrm{Li}^{+}$in the three-dimensional spinel framework [11]. The $\mathrm{Li} / \mathrm{Li}_{0.53} \mathrm{H}_{0.13} \mathrm{Cs}_{0.14} \mathrm{Ti}_{1.65} \mathrm{Mg}_{0.30} \mathrm{O}_{4}$ cell exhibited almost the same voltage as shown in the figure, so we can conclude that the discharge process corresponds to the intercalation of $\mathrm{Li}^{+}$into the vacant space of the interlayer and the reduction of $\mathrm{Ti}^{4+}$ to $\mathrm{Ti}^{3+}$ in the lepidocrocite structure. 


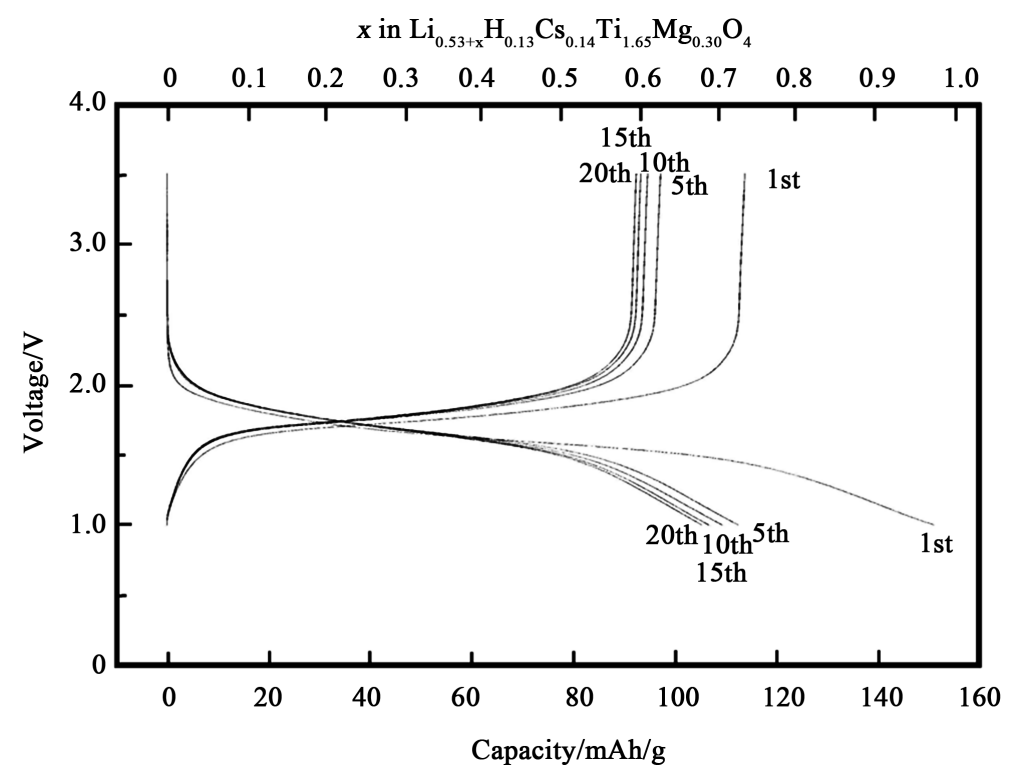

Figure 4. Discharge-charge curves of $\mathrm{Li} / \mathrm{Li}_{0.53} \mathrm{H}_{0.13} \mathrm{Cs}_{0.14} \mathrm{Ti}_{1.65} \mathrm{Mg}_{0.30} \mathrm{O}_{4}$ cell with 0.10 $\mathrm{mA} / \mathrm{cm}^{2}$.

The first discharge and charge capacities were $151 \mathrm{mAh} / \mathrm{g}$ and $114 \mathrm{mAh} / \mathrm{g}$, respectively. The amounts of $\mathrm{Li}^{+}$intercalated and deintercalated were 0.98 and 0.74 of the formula unit, respectively. At the 10th cycle, the cell exhibited $73 \%$ $(110 \mathrm{mAh} / \mathrm{g})$ of the first discharge capacity and $83 \%(95 \mathrm{mAh} / \mathrm{g})$ of the first charge capacity. At the 20th cycle, the cell exhibited $70 \%(105 \mathrm{mAh} / \mathrm{g})$ of the first discharge capacity and $82 \%(93 \mathrm{mAh} / \mathrm{g})$ of the first charge capacity.

\subsection{Sodium Battery}

Figure 5 shows the discharge-charge curves of $\mathrm{Na} / \mathrm{Li}_{0.53} \mathrm{H}_{0.13} \mathrm{Cs}_{0.14} \mathrm{Ti}_{1.65} \mathrm{Mg}_{0.30} \mathrm{O}_{4}$ cell. The cell voltage decreased rapidly from the rest potential of $2.7 \mathrm{~V}$ to $1.8 \mathrm{~V}$ and then decreased slowly to the cutoff voltage of $0.70 \mathrm{~V}$. The discharge capacity was $91 \mathrm{mAh} / \mathrm{g}$ for the first cycle. The amount of $\mathrm{Na}^{+}$intercalated in this process was 0.59 for the formula unit. Recently, we reported that $\mathrm{Li}_{2} \mathrm{Ti}_{5} \mathrm{O}_{11}$ derived by ion-exchange reaction from the layer-structured titanate $\mathrm{Cs}_{2} \mathrm{Ti}_{5} \mathrm{O}_{11}$ exhibited discharge-charge capacities of 120 and $100 \mathrm{mAh}$, respectively, for the first cycle in a rechargeable sodium battery in the voltage range $0.70-4.0 \mathrm{~V}$ [8]. The discharge potential of $\mathrm{Ti}^{4+} / \mathrm{Ti}^{3+}$ in the layer-structured $\mathrm{Li}_{2} \mathrm{Ti}_{5} \mathrm{O}_{11}$ was approximately $1.2 \mathrm{~V}$ with the insertion of $\mathrm{Na}^{+}$. This shows that the discharge process of the $\mathrm{Na} / \mathrm{Li}_{0.53} \mathrm{H}_{0.13} \mathrm{Cs}_{0.14} \mathrm{Ti}_{1.65} \mathrm{Mg}_{0.30} \mathrm{O}_{4}$ cell corresponds to the intercalation of $\mathrm{Na}^{+}$and the reduction of $\mathrm{Ti}^{4+}$ to $\mathrm{Ti}^{3+}$ in the lepidocrocite structure.

The first discharge and charge capacities were $91 \mathrm{mAh} / \mathrm{g}$ and $77 \mathrm{mAh} / \mathrm{g}$, respectively. The amounts of $\mathrm{Na}^{+}$intercalated and deintercalated were 0.59 and 0.50 of the formula unit, respectively. At the 10th cycle, the cell exhibited $64 \%$ $(58 \mathrm{mAh} / \mathrm{g})$ of the first discharge capacity and $73 \%(56 \mathrm{mAh} / \mathrm{g})$ of the first charge capacity. At the 20th cycle, the cell exhibited $38 \%(35 \mathrm{mAh} / \mathrm{g})$ of the first discharge capacity and $44 \%$ (34 mAh/g) of the first charge capacity. 


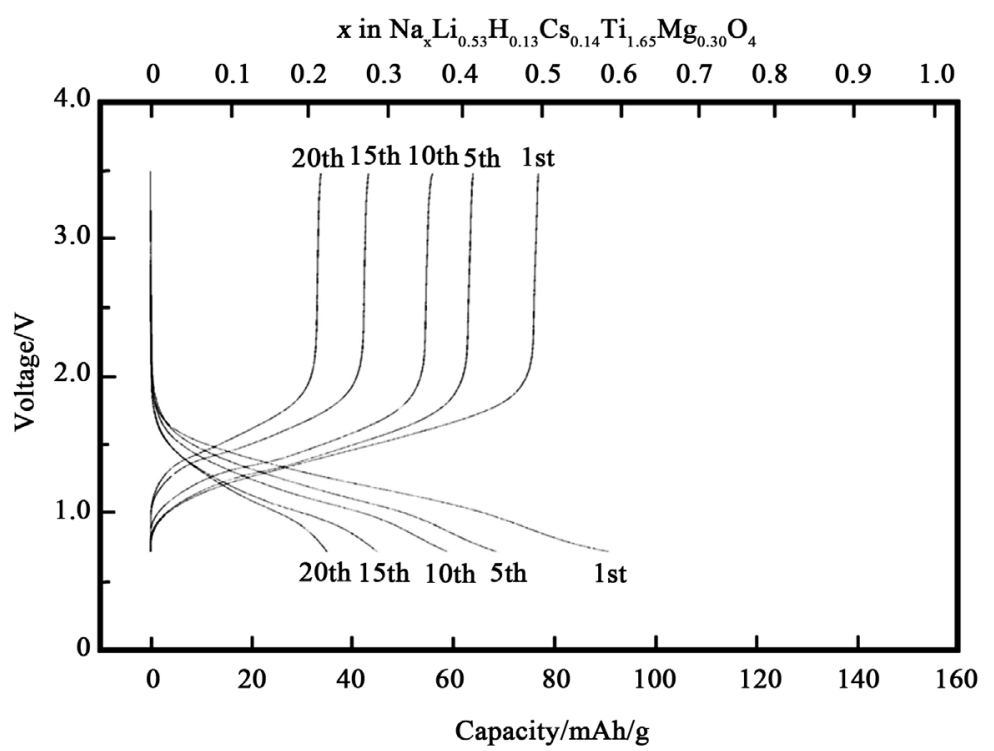

Figure 5. Discharge-charge curves of $\mathrm{Na} / \mathrm{Li}_{0.53} \mathrm{H}_{0.13} \mathrm{Cs}_{0.14} \mathrm{Ti}_{1.65} \mathrm{Mg}_{0.30} \mathrm{O}_{4}$ cell with 0.10 $\mathrm{mA} / \mathrm{cm}^{2}$.

The lower discharge-charge capacity of the sodium battery compared with that of the lithium battery may be attributed to the difference in ionic volume of $\mathrm{Na}^{+}$and $\mathrm{Li}^{+}$. The larger volume of $\mathrm{Na}^{+}$as compared with $\mathrm{Li}^{+}$has a disadvantage in the intercalation into the vacant space of the interlayer.

\section{Conclusion}

In this study, we showed for the first time that layer-structured titanate $\mathrm{Li}_{0.33} \mathrm{Cs}_{0.37} \mathrm{Ti}_{1.65} \mathrm{Mg}_{0.35} \mathrm{O}_{4}$ derived from $\mathrm{Cs}_{x} \mathrm{Ti}_{2-x / 2} \mathrm{Mg}_{x / 2} \mathrm{O}_{4}(x=0.70)$ with lepidcrocite-type structure by ion exchange can be a promising candidate for the cathode materials of both sodium and lithium ion batteries. The titanate is non-toxic, inexpensive, and environmentally benign.

\section{Conflicts of Interest}

The author declares no conflicts of interest regarding the publication of this paper.

\section{References}

[1] Ohashi, M. (1998) Preparation and Lithium Intercalation of Layer Structured Titanate $\mathrm{Cs}_{x} \mathrm{Ti}_{2-x / 4} \mathrm{O}_{4}(x=0.68)$. Molecular Crystals and Liquid Crystals, 311, 51-56. https://doi.org/10.1080/10587259808042365

[2] Ohashi, M. (2000) Ion Exchange of Layer Structured Titanate $\mathrm{Cs}_{x} \mathrm{Ti}_{2-x / 4} \mathrm{O}_{4}(x=0.68)$ and Ionic Conductivity of the Products. Molecular Crystals and Liquid Crystals, 341, 265-270. https://doi.org/10.1080/10587250008026151

[3] Ohashi, M. (2002) Preparation of Layer Structured Crystal Cs $\operatorname{Ti}_{2-x} \mathrm{Mn}_{x} \mathrm{O}_{4}(x=0.70)$ and Application to Cathode for Rechargeable Lithium Battery. Key Engineering Materials, 216, 119-122. https://doi.org/10.4028/www.scientific.net/KEM.216.119

[4] Ohashi, M. (2002) Preparation of Layer-Structured Crystal $\mathrm{K}_{x} \mathrm{Ti}_{2-x} \mathrm{Mn}_{\mathrm{x}} \mathrm{O}_{4}(x=0.75)$ 
and Application as Cathode Material in Rechargeable Lithium Battery. Key Engineering Materials, 228-229, 289-292.

https://doi.org/10.4028/www.scientific.net/KEM.228-229.289

[5] Ohashi, M. (2004) Preparation and Ion Exchange of Layer Structured Cesium Chromium Titanate $\mathrm{Cs}_{x} \mathrm{Ti}_{2-x} \mathrm{Cr}_{x} \mathrm{O}_{4}(x=0.70)$. Journal of the Ceramic Society of Japan, Supplement, 112-1, S114-S116.

[6] Ohashi, M. (2004) Preparation of Layer Structured Titanate $\mathrm{Cs}_{x} \mathrm{Ti}_{2-x} \mathrm{Fe}_{x} \mathrm{O}_{4}(x=0.70)$ and Application as Cathode Material in Rechargeable Lithium Battery. Solid State Ionics, 172, 31-32. https://doi.org/10.1016/j.ssi.2004.01.035

[7] Ohashi, M. (2009) Ion Exchange of Layer Structured Crystal $\mathrm{K}_{x} \mathrm{Ti}_{2-x} \mathrm{Fe}_{x} \mathrm{O}_{4}(x=0.70)$ and Its Application as Cathode Material in a Rechargeable Lithium Battery. Key Engineering Materials, 388, 97-100.

https://doi.org/10.4028/www.scientific.net/KEM.388.97

[8] Ohashi, M. (2018) Novel Cathode Materials for Sodium Ion Batteries Derived from Layer Structured Titanate $\mathrm{Cs}_{2} \mathrm{Ti}_{5} \mathrm{O}_{11} \cdot(1+x) \mathrm{H}_{2} \mathrm{O}$. Materials Sciences and Applications, 9, 526-533 https://doi.org/10.4236/msa.2018.96037.

[9] Reid, A.F., Mumme, W.G. and Wadsley, A.D. (1968) A New Class of Compound $\mathrm{M}_{x}^{+} \mathrm{A}^{3+}{ }_{x} \mathrm{Ti}_{2-x} \mathrm{O}_{4}(0.60<x<0.80)$ Typified by $\mathrm{Rb}_{x} \mathrm{Mn}_{x} \mathrm{Ti}_{2-x} \mathrm{O}_{4}$. Acta Crystallographica, B24, 1228-1233. https://doi.org/10.1107/S0567740868004024

[10] England, W.A., Birkett, J.E., Goodenough, J.B. and Wiseman, P.J. (1983) Ion Exchange in the $\mathrm{Cs}_{x}\left[\mathrm{Ti}_{2-x / 2} \mathrm{Mg}_{x / 2}\right] \mathrm{O}_{4}$ Structure. Journal of Solid State Chemistry, 49, 300-308. https://doi.org/10.1016/S0022-4596(83)80007-3

[11] Ohzuku, T., Ueda, A. and Yamamoto, N. (1995) Zero-Strain Insertion Material of $\mathrm{Li}\left[\mathrm{Li}_{1 / 3} \mathrm{Ti}_{5 / 3}\right] \mathrm{O}_{4}$ for Rechargeable Lithium Cells. Journal of the Electrochemical Society, 142, 1431-1435. https://doi.org/10.1149/1.2048592 